\title{
Szemle
}

\section{Így kell védenie a munkajognak a munkavállalót?}

\author{
Recenzió Kiss György: \\ A foglalkoztatás rugalmassága és a munkavállalói jogállás védelme \\ (Egy lehetséges megközelítés \\ a munkaviszony tartalmának vizsgálatához) címü könyvéröl
}

\author{
Is This the Way Labour Law Should Protect the Employee? \\ Review of György Kiss's New Book
}

\begin{abstract}
ABSZTRAKT
Recenziónkban Kiss György A foglalkoztatás rugalmassága és a munkavállalói jogállás védelme (Egy lehetséges megközelítés a munkaviszony tartalmának vizsgálatához) címü könyvét mutatjuk be. A mü a munkajogi szabályozás jövőjének kérdését feszegeti, a múltban elért eredmények és megállapítások felhasználásával. A római jogi gyökerek ismertetését követően a germán, frankofon és angolszász jogrendszerek fejlődésén át ismerhetjük meg a munkajogi szabályozás jelenlegi formájának kialakulását. A történeti sík mellett a dogmatikai alapok felvázolására is sor kerül a munkában, így a munkaszerződés tartalmi feldolgozása több síkon is megtörténik, mielőtt a szerző - az általa felvetett - relational contract elméletének munkajogi alkalmazhatóságáról értekezne. Mindezen alapok ismertetése alkalmassá teszi a müvet arra, hogy a munkajog iránt érdeklődők a különböző jogrendszerek szerződéses elméleteit is jobban megismerhessék és megértsék. A recenzió által úgy kívánunk betekintést adni a szerző munkájába, hogy saját személyes szürőnk és véleményünk is megjelenik a leírtakról.
\end{abstract}

Kulcsszavak: munkavállalók jogállása, relational contract elmélete, a munkajog rugalmasabbá válása, munkaszerződés elemei, ígéret

ABSTRACT

Our review is about György Kiss's book, its title being Employment Flexibility and the Protection of Employee Status (A Possible Approach to Examining the Content of the Employment Relationship). The work raises the question of the future of labour law regulation, using the results and

* Dr. Bankó Zoltán, egyetemi docens, Pécsi Tudományegyetem Állam- és Jogtudományi Kar, Munkajogi és Társadalombiztosítási Jogi Tanszék, e-mail: banko.zoltan@ajk.pte.hu. Dr. Rab Henriett, egyetemi docens, Debreceni Egyetem Állam- és Jogtudományi Kar, Környezetjogi és Munkajogi Tanszék, e-mail: rab.henriett@ law.unideb.hu. 
findings of the past. After describing the roots of Roman law, we can learn about the development of the current form of labour law through the development of the Germanic, Francophone and Anglo-Saxon legal systems. In addition to the historical view, the dogmatic foundations are also outlined in the work, so the content processing of the employment contract takes place on several levels before the author discusses the labour law applicability of the relational contract theory he raises. The description of all these bases makes the work suitable for those interested in labour law to better understand the contractual theories of different legal systems. We want to give an insight into this in the review, so that in addition to presenting the work, our own personal views and opinions will also appear.

Keywords: legal status of workers, relational contract theory, making labor law more flexible, elements of the employment contract, promise

Kiss György akadémikus monográfiája 2020-ban jelent meg a Wolters Kluwer Hungary gondozásában, a kötet a munkajog tudományának művelőit hosszú évek óta foglalkoztató kérdésekre ad történetileg és dogmatikailag megalapozott válaszokat. A mű jól illeszkedik a szerző munkásságába, aki akadémiai székfoglaló előadását ${ }^{2}$ is a témában tartotta. Magánjogi szemléletü kutatómunkája keretében különböző aspektusokból vizsgálta már a munkajogot, az MTA doktori címének alapjául szolgáló könyve pedig az alapjogok munkajogi kollízióját ${ }^{3}$ dolgozta fel. Ezen munkásság egy újabb jelentős állomása a recenzióban értékelésre kerülő munka.

A mủ nagy erénye, hogy a különböző álláspontokra helyezkedő szakemberek számára egyaránt tartalmaz elgondolkodtató információkat, érveket. Munkajogász körökben egy-egy témakör elemzése kapcsán fel-felmerül, hogy hogyan kellene a témához közelítenünk, milyen mélységig görgessük vissza egy-egy szál fonalát, ahhoz, hogy meg tudjuk ítélni a szabályozás alapját, módszerét, szükségességét. Ebben a könyvben a szerző ezt a munkát széles körben végzi el, példamutató módon használja fel a római jogi alapokat és a modern munkajogi dogmatikát egyaránt. Ha irodalmi publicisztikát írnánk, akkor egy cirkuszi kötéltáncos képét festenénk le, amint a két pillér között professzinális módon, a lehetőségeit a végletekig kihasználva mutatná be, mit is lehet kihozni egy ilyen produkcióból. Félretéve a képzettársításokat, egy olyan mủ bemutatására teszünk most kísérletet, mely magában rejti egy életút tudásának, kutatómunkájának, együttgondolkodásainak tapasztalatait és betekintést ad számunkra egy koncepciózus elmélet felépítésének szakmai folyamatába. Vékás Lajos ajánlásában úgy fogalmaz, hogy „Kiss György akadémikus legújabb könyve igazi szellemi ajándék a jogelmélet és a joggyakorlat számára egyaránt."4 Magunk is egyetértünk ezzel a megállapítással. Kiss György úgy keresi a munkaszerződés helyét a jogrendszerekben, hogy a fogalmi elemek - mint az ígéret - és a tartalmi elemek - mint a munkáltatói jogkör - vizsgálatát a szabályozást indukáló gazdasági és társadalmi környezetben is elhelyezi, segítve ezzel az egyes jog-

${ }^{1}$ KISs György: A foglalkoztatás rugalmassága és a munkavállalói jogállás védelme (Egy lehetséges megközelítés a munkaviszony tartalmának vizsgálatához). Wolters Kluwer Hungary, Budapest, 2020, 316 o.

${ }^{2}$ A 2016. október 27-én megtartott akadémiai székfoglaló előadás címe: A foglalkoztatás rugalmassága és a munkavállalói jogállás védelme - új megközelítések a munkajogviszony tartalmának vizsgálatához.

${ }^{3}$ KIss György: Alapjogok kollíziója a munkajogban, Justis Tanácsadó Betéti Társaság, Pécs, 2010.

${ }^{4}$ Vékás Lajos: Ajánlás. In: Kiss (2020): i. m., 11. 
intézmények kialakulásának megértését is. A recenzió elkészítésére a mély szakmai tisztelet kifejezése mellett azért vállalkoztunk, hogy a szélesebb közönség számára is felvázoljuk a könyvben rejlő további kutatási lehetőségeket. A könyv olvasása során számos olyan pontot találtunk, mely egy-egy kollégánk kutatását érinti, így a recenzió megírása során törekszünk a megközelítés sokszínüségére is rávilágítani.

\section{A monográfia felépítése}

A Bevezetésben foglalt áttekintés felvázolja az olvasó számára a további fejezetek logikai ívét; a feltett kérdések révén elöre megnyugtatja az érdeklődőket a későbbiekben kifejtett gondolatok racionalitását, dogmatikai megalapozottságát illetően; a múltat a jövővel összekötve kerít sort a munkaszerződés fogalmi kereteinek újragondololására. A munkajogviszony megváltozott koordinátarendszerbe helyezése a munkajogi keretekben egyfajta elbizonytalanodást eredményezhetne, azonban a későbbi fejezetekben részletesen is elemzett fogalmi rendszer révén a szerző a munkaszerződést elemeire szedi és újból összerakja, mely folyamat végén megerősítést is nyer a munkajogi dogmatika megfelelősége. Egyúttal több kutatás lehetséges kiindulópontja is megszületik, hiszen mindez a munkajog tartalmának, azon belül is az egyes jogintézményeknek az újragondolását is lehetővé teszi.

A tanulmány első fejezete A munkaszerződés múltbeli gyökerei címet viseli. Ebben a fejezetben kerül sor a római gyökerek feltárása mellett a római jog továbbélésének vizsgálatára a francia jogban, a pandektajogban és az angol common-law rendszerében. E körben sor kerül a munkajog alapjának tekintett római jogi jogintézmény - a locatio conductio operarum - kijelölésére és bemutatására, úgy, hogy a szabályozás jogpolitikai indokaira is keresi a választ, mely kellő megalapozását adja a monográfia későbbi fejezeteiben foglalt - már említett - fogalmi rendszernek.

Számunkra fontos fejezet a könyv második fejezete, melyben az ígéret fogalmi elmezéséről, majd a három jogrendszerben való elhelyezéséről olvashatunk. Evidenciaként kezeli a szerző az ígéret fogalmi jelenlétét a jogi szabályozásban, melyre alapvetően sem a jogászképzés keretei között a joghallgatók, sem a jogrendszer működése körében a jogalkalmazók figyelmét a jogszabályok értelmezésekor nem hívják fel. Az ígéret elemzésével olyan új nézőpontot nyer az olvasó, mely meszszebb visz a klasszikus jogértelmezési metódusoktól és a jogintézmény rendeltetése, szükségessége, a szabályozási módszer jobb megértése révén - Kiss György szóhasználatában ${ }^{5}$ - „rétegeket” ad a jogi szabályozásnak. A következő fejezetekben ezekre a rétegekre világít rá a könyv, melyet továbbgondolva az olvasók is újabb és újabb szintjeit tudják feltárni a vizsgált kérdéseknek.

A harmadik fejezet a szerződések tana szempontjából vázolja fel történeti síkon a szerződés tartalmi átalakulásának folyamatát, mely egyrészt a munkajog kialakulásának okait tárja fel, egyúttal igazolva a munkajog önállóvá válásának szükségszerűségét. Másrészt a polgári jogi gyökerek jelentőségét is értékeli a munkajogi szabályozás megítélése érdekében. Harmadrészt a szerző teóriája szempontjából

\footnotetext{
${ }^{5}$ KISS (2020): i. m.; a 2.1. pont Az ígéret eltérő dimenziói/rétegei a munkajogban címet viseli.
} 
végállomást jelentő relational contract elméletét is beleilleszti az elemzés ezen folyamatába. A teória alkalmazásának megalapozásával hitelessé és érthetővé válik a szerző koncepciója e körben. A vizsgálat alá vont relational contract munkajogi alkalmazásának célja a munkajog karakterének megőrzésével a „rugalmas stabilitás” elérése, mely így a munkajog egyik legfontosabb megoldandó problémájára adott válaszként is szolgál. Kiss György által megfogalmazottan a munkajog „a tradicionális magánjog máig élő szerződési szabadsága és a munkavállaló jogállásának védelme között örlődik, és ez utóbbit igyekszik valamilyen elfogadható indokkal alátámasztani." 6

Kézenfekvő módon a következő fejezet a munkajogviszony tradicionális jellemzőinek bemutatását tartalmazza, melyből a munkajogviszony tartam jellegét emeli ki a szerző, illetőleg az alá-fölérendeltséget, melynek jogi természetét elemezve a korábbi fejezetek - római jogi gyökerek, illetöleg az ígéret - körében felvázolt ismeretek összekapcsolásával a relational contract alkalmazásához vezető út is kivilágosodik.

Az ötödik fejezetben a magánjogban részletesen elemzett - a munkajogtól eddig idegen - alakító jog elemzésével a szerző aktualizálja munkáját: a korábbi, történeti síkon bemutatott ismereteket integrálja az egyoldalú alávetettséget kifejező munkajog relációjába. A munkajogban ható alakító jog ellentmondásosságának elismerésével és a magánjogtól szűkebb értelmezésével Kiss György megteremtette a a munkáltatói hatalomnak és az alá-fölérendeltségnek, mint a munkáltató egyoldalú döntési hatalmának az igazolására szolgáló magánjogi gyökeret, melynek jelentősége abban fogalmazható meg, hogy a klasszikusabb, társasági jogi alapú szervezeti tulajdonból és a vezetési/szervezési jogkörből levezethető tulajdonosi joggyakorlás és az ennek korlátot szabó közjogias szabályozás helyett lehetőséget kínál a magánjogi alapú gondolkodásra a munkáltató jogkörének megítélése körében.

A gondolati ív lezárásaként a szerző a hatodik fejezetben a munkaszerződést mint lehetséges relational contractot elemezte, külön vizsgálva e körben a munkaszerződést és annak joghatását, illetőleg a munkajog tartalmi követelményeit. Az elemzés keretei között a klasszikus magánjogi kötődésü, individuális munkajogi elemek mellett a kollektív munkajog intézményeinek szerepét is megismerhetjük a relational contract viszonylatában, egy újabb elemmel - a tisztességtelen szerződési feltételek problematikájával - kiegészítve a munkajog magánjogi intézményekkel való párhuzamba állítását.

A fejezet végén és egyben a monográfiában vázolt elmélkedés lezárásaként Kiss György a munkajog védelmi szerepének legerősebb területét jelentő jogviszony megszüntetés kérdésében foglal állást, úgy hogy a relational contract elmélet szerződés fenntartására való törekvését igyekszik együtt vizsgálni a munkajog munkaerőpiaci szerepével. Bár a szerző a bevezetőjében tisztázza, hogy a tételes magyar munkajogi szabályozás tekintetében munkájában nem kíván mélyreható elemzéseket végezni, e körben mégis sor kerül a példaként említett három modell mellett a hazai szabályozás gazdasági okra alapozottan szélsőséges jogalkotói megoldásának és az arra adott jogalkalmazói válasznak a kritikiai bemutatására. ${ }^{7}$ A szerző bevezetőben

\footnotetext{
${ }^{6}$ KISS (2020): i. m., 268.

${ }^{7}$ Kiss (2020): i. m., 274-275.
} 
deklarált ezen célkitűzésével nem feltétlenül értettünk egyet, hiszen a magyar szabályozás megítélése éppoly értékes része lett volna a munkának, mint a bemutatott germán, frankofon és angolszász jogrendszerek fejlődése a monográfia tárgykörében. Azonban ezen a ponton, mikor a korábbiakban vázolt erős magánjogi szempontú megközelítés mellett előbukkant a szerző több évtizedes munkajogi munkásságának hatására kimondott kritikája, akkor igazolva láttuk ezen döntés helyességét: itt nem tudott a szerző az elméleti leíró szinten maradni, ahogy azt végig tartotta a munkája során, hanem a joggyakorlat és a jogalkotás ellentmondásosságának részletei vonatkozásában foglalt indokoltan, bár a téma szempontjából talán kicsit túlzott alapossággal állást.

Az előző pont lezárását követően - ezen a gondolati íven továbbhaladva a monográfia utolsó felütése és talán nem túlzás a kifejezés: csattanója, a Létezik-e, illetve szükséges-e a new social contract? címet viseli. Kiss György akadémikus a 274 oldalon keresztül kiérlelt elméletére is kiterjedően fogalmazta meg összefoglaló gondolatait, melyek nem túl optimistára sikerültek. A felek közötti imparitás okán „legalábbis kérdésesnek” minősíti a relational contract elemeinek alkalmazását a munkaszerződés vonatkozásában, arra figyelemmel, hogy a „munkavállaló olyan szerződés alanya, amely eredményének további sorsára nincs befolyása."

A következőkben megpróbálunk rávilágítani a szerző - megítélésünk szerint kiemelendő gondolataira, melyek eredményeként a munkajog „sodródó” helyzetét ${ }^{9}$ állapította meg konklúzióként.

\section{Néhány gondolat a monográfiából}

A munka kiindulási alapját a munkaszerződés - illetve annak történelmi előzményeit adó szerződési típusok - és a polgári jogi szerződés közös gyökereinek felgöngyölítése adta, melynek keretében a munkajog polgári jogi jogviszonyoktól való elhatárolásának szempontjait vette a szerző elemzés alá. E körben nem kerülhette meg a klasszikus szerződéstani különbségtétel alkalmazását, azonban mégis hozott új elemeket, nézőpontokat vizsgálatában. A szerző mind az előszóban, mind a további fejezetek bevezetéseként kérdéseket feltéve konkretizálta hipotéziseit.

A munkajog kötelmi rendszerből való kiválását - melyet az I. és a II. fejezetben a római jogtól a polgári jogi kodifikációk időszakáig követett nyomon - már az előszóban is azzal indokolta a szerző, hogy a későbbi munkaszerződés a kötelmi jog rendszerébe egyre inkább kényelmetlenül illeszkedett, ami miatt csapódott a magánjoghoz és a közjoghoz egyaránt. ${ }^{10} \mathrm{Ez}$ az állítás alapjaiban kérdőjelezi meg a munkajog „keresztülfekvő"11 és így a jogterületek közötti hiátuson átívelő jogági jellegének ideológiáját. Az elhatárolás szempontjait sok esetben a munkaviszony

\footnotetext{
${ }^{8}$ KISS (2020): i. m., 278.

${ }^{9}$ KISS (2020): i. m., 279.

${ }^{10}$ KISS (2020): i. m., 13.

11 Sárközy Tamás több munkájában használja ezt a kifejezést, melyet a jogirodalom is elfogadott. SÁRKÖzY Tamás: A gazdasági jog és az új Polgári Törvénykönyv. Gazdaság és Jog, 2012/3., 3-7.
} 
tartalmának eltérő jellegében ragadják meg, így Kiss György sem kerülhette meg az Általános helyzetfelmérés című bevezető fejezetben azt, hogy a munkajog és a magánjog klaszikus elhatárolása tekintetében elemzésekbe kezdjen. Kiindulási alapjai körében felhasználta Flume azon gondolatát, mely szerint a magánjogi jogügyletek során a partnerek egyenlőtlen pozíciója szinte általános, azonban ez nem jelenti azt, hogy a gyengébb fél önrendelkezési joga és alkupozíciója is feltétlenül csorbul. ${ }^{12}$ A dolgozat további fejezeteiben a munkajogi sajátosságok, az alá-fölérendeltség vagy akár az alakító jog elemzése kapcsán sem feledkezik meg erről a hipotézisről.

Hasonlóan alapvető megközelítés a munkajognak a közjog oldaláról való vizsgálata, mely szintén általános vizsgálati szempont, azonban a magánjog oldaláról bemutatva a kérdést Kiss György rámutat, hogy a közjogi elemek munkajogi jelenlétét az indukálta, hogy a szabályozás fejlődése során a megjelenő szociális elemek nem fértek el a magánjog kötelmi rendszerében, majd ezek további erősödésük által olyan intézményekkel gazdagították a munkajogviszony tartalmát, melyek már a tradicionális magánjogtól idegenek voltak. ${ }^{13}$ Ezen hipotézik igazolására is sor kerül - a II. fejezetben taglalt ígéret jelentőségét is felhasználva - az V. fejezetben, ahol a magánjogi alakító jogból kiindulva a munkaviszony tartalmát alakító munkaszerződést a közjogi szabályozás indoka és a jogszabályi előírások (garanciák) rendeltetése szempontjából is elemzés alá veszi a szerző.

Mindezen alapvető feltételezések mellett egy harmadik kipotézist is felállít Kiss György, rögtön az előző kettőből következően, amikor kimondja, hogy a „munkajog és a magánjog kapcsolatának van még egy sajátos szegmense, nevezetesen a munkajog szerkezete."14 Ezzel az individuális és a kollektív munkajog együttes jelenlétére utal a szerző. Míg az individuális munkajog kötelmi jogi gyökerét a munkaszerződés és annak elemei adják, addig a kollektív megállapodás esetében ez már nem mondható ki: a normatív tartalom, sőt a jogviszony alanya tekintetében is megkérdőjeleződik a magánjog szerepe. Külön kiemelhető e körben a sztrájkhoz való jog, mely alapjogi jelleget is ölt. Ezen gondolati síkot a szerző a munkajogban megjelenő új munkavállalási és foglalkoztatási módszerekkel is párhuzamba állítja, kimutatva ezáltal, hogy a probléma nem csak a kollektív munkajogok körében érhető tetten. Számunkra ez a megállapítás azért is hasznosnak bizonyult, mert ezen újtípusú munkavégzési formák esetében a szakmai diskurzusban az az alapvető cél, hogy a munkajog klasszikus szerződéses tartalmi elemeinek jelenléte, ezáltal a munkaszerződés létjogosultsága igazolásra kerüljön, nem fogadva el azon kézenfekvő tényt, hogy vannak a munkajogban olyan közjogi szabályozók, melyek nem illenek bele a magánjogi szerződéses eszköztárba. Azaz nem kell beleerőltetni az oda nem illő elemeket; ha közjogi segítséggel elfogadottá teszünk új tartalmi elemeket, attól azok még részévé válhatnak a munkajognak. Ennek lehetőségét és körülményeit a jövőbeli tudományos munkákban érdemesnek látjuk feldolgozni. A szerző maga ezzel kapcsolatosan „tanulmánya” célját akként határozta meg, hogy „annak feltárására törekszik, hogy hogyan lehet a munkaviszony tartalmát több kitérőt köve-

12 FLumE, Werner: Allgemeiner Teil des bürgerlichen Rechts. Spinger Verlag Berlin, 1979, 10.

${ }^{13}$ Kiss (2020): i. m., 14.

${ }^{14}$ Kiss (2020): i. m., 14. 
tően (mely kitérőket be is mutat a történeti fejezetekben) ismét szerződéses alapon minősiteni." 15

Kiss György munkájában számos konkrét kérdést is megfogalmaz, melyek a munkajog tudományában folyamatosan jelen lévő dilemmát jelentenek, válaszait azonban egy általa felvázolt új magánjogi és történeti dogmatikai síkon igyekszik megadni. Néhány kérdés e körben:

Milyen szerződés az, amely a megállapodástól lényegesen eltérő tartalommal rendelkező jogviszonyt keletkeztet? ${ }^{16}$

Elképzelhető-e egységes elveken nyugvó munkajogi szerződéses rendszer (munkaszerződéses, kollektív szerződéses) rendszer? ${ }^{17}$

Miért nem sikerült mindeddig a rugalmasság és státuszbiztonság stabil jogi struktúráját felállítani? ${ }^{18}$

Le lehet-e írni a munkajogot egyetlen szerződéssel, illetve egyetlen jogviszonynyal ${ }^{19}$ A munkaszerződés jelenlegi egysége az egyre inkább differenciálódó tartalma ellenére képes-e adekváltan leírni a munkajog jelenlegi állapotát? Vagy az egyes munkatípusok annyira eltérnek egymástól, hogy a szerződés, illetve szerződések diverzitását hozza magával?

Honnan származnak a szerződésben, így a munkaszerződésben benne rejlő vagy beleértett feltételek? Kizárhatják-e a felek a szerződésben benne rejlö feltételeket? ${ }^{20}$

Mennyiben hat a munkaszerződés alanyaira az egymásrautaltság, a kölcsönösség? ${ }^{21}$ Mely kérdéssel is végső soron arra keresi a választ, hogy Minősíthetjük-e a munkaszerződést relational contract-nak.

A monográfia összegző fejezete körében megfogalmazódó végső kérdés: egy ilyen összetett, több vonatkozásban vitatott szerződéses elméletre lehet-e alapozni a munkaszerződés egyik lehetséges fejlődési irányát? Erre a sommás válasza a szerzőnek: „Álláspontom szerint nem."22 Olvasóként az első reakciónk erre egy felhúzott szemöldök lehet, melyet esetünkben következő reakció gyanánt rögtön a kiváltott tisztelet követett: Kiss György professzor úgy írta meg munkáját, hogy tisztában volt a hipotézise ingatagságával, mégis a munkájával elérhető eredmények hasznát előrébb sorolta, mint a kutatása „sikerességét." Számunkra a munka eredménye, hogy

\footnotetext{
${ }^{15}$ Kiss (2020): i. m., 15.

${ }^{16}$ A munkajogviszony sokat emlegetett függő jellegét és tartamjellegét érti a szerző a megállapodástól alapvetően különböző elemeiként a munkaviszonynak, hiszen ezekről a munkaszerződésben nem születik megállapodás. „A jogi norma szerepe a státusz fenntartása, a szerződéses szabályozás pedig a jövőbeli változás helyzetét igyekszik kezeni." Kiss (2020): i. m., 32.

${ }^{17}$ A kérdésre nem a jogalkotásban, hanem a jogalkalmazásában látja a szerző a választ felsejleni, a multinacionális vállalkozások belső normái révén.

${ }^{18}$ Különösen érdekes a kérdés, ha az ipari forradalom óta eltelt idő aktív mukaharcára és az annak eredményeként megszületett nemzetközi és nemzeti szintű jogalkotásra gondolunk, hiszen ezáltal a közjogi keretek biztosítottak, a szabályozás tartalmi meghatározásában a nemzetközi összhang is biztosítható.

${ }^{19}$ A kérdés jövőbemutató, hiszen alapvető dilemma a munkajogban az újonnan megjelenő foglalkoztatási formák beillesztése a munkajogi keretek közé, mely nézőpontot a szerző folyamatosan szem előtt tartott a könyv megírása során.

${ }^{20}$ A kérdések az implied terms viszonylatában merültek fel. Kiss (2020): i. m., 221.

${ }^{21}$ KISS (2020): i. m., 277.

${ }^{22}$ KISS (2020): i. m., 278.
} 
alapjaira szedte szét a munkajog már vizsgált és egyébként külön-külön feldolgozott intézményeit, és a dogmatikai vizsgálatot követően újra összeillesztve az elemeket olyan pluszt adott a korábbi anyagokhoz, mely az új munkajogi szabályozási problémák megoldását is segítheti a következőkben.

A munkajog jelenleg formálódó szerepét és fejlesztési irányait tekintve pesszimista álláspontot képvisel a szerző valamennyi jelenleg népszerủ megoldási javaslat tekintetében, amikor sem a tradicionális munkajogot megőrző, a szociális stabilitásra törekvő szabályozást nem tartja kivitelezhetőnek, sem a liberalizált „szinte szabad foglalkoztatást", sem a klasszikus szerződési elvekhez való visszatérést (amihez a relational contract elméletét fel is dolgozta). Azon dilemmából indul ki a következtetések körében, hogy a „szociális stabilitás fenntartása valóban csak úgy lehetséges-e, hogy meghatározott területeken a rugalmasság érdekében a közösségi jog bizonyos alapértékei erodálódjanak?"23 Ez az ellentmondásosság a munkajogi szabályozás egészében jelen van. A munkajog kapcsolatrendszeréből erednek olyan morális töltésủ követelmények, melyek ,jogiasítása” számos esetben bizonytalanságot okoz. ${ }^{24}$ Ezek rendezése érdekében - Macneil álláspontját idézve - közvetítő normák beiktatása szükséges. ${ }^{25} \mathrm{~A}$ munkajogra vonatkoztatva a relation contract tartalmát meghatározó role integrity a szerző álláspontja szerint kevéssé megvalósítható - nincs olyan szinten a felek kapcsolata (a felek közötti imparitás miatt), hogy kölcsönösen elfogadják a másik társadalmi helyzetét és az ebből fakadó magatartásokat. Ezen konklúzió mentén nyer értelmet a szerző hosszas vizsgálata az ígéret és alakító jog körében, amely a munkajog tartós jogviszony jellegének meghatározásakor is sajátosságokat eredményez: a felek viszonyrendszere, egymásrautaltsága megteremti-e a relatation contract körében elvárt szintet (a munkajog státuszállapotát), amely nem csak egy tartósra tervezett kötelmet jelent, hanem egyúttal elvárja a felek hajlandóságát is arra, hogy tevőleges magatartásukkal segítsék ezt elő.

\section{Gondolatok az olvasottakból kiindulóan}

A monográfiában fontos elemnek tartjuk, melyen a munkajog tudományának - függetlenül a relation contract elméletétöl - dolgoznia kell, hogy a szerződéskötéskori ígéretek meghatározása és a feltételek kijelölése körében a jövőre vonatkoztatott tervezést szükséges a felek kultúrájába megteremteni. A szerző gondolatai között e körben megjelenik a felek felelőssége a szerződés előkésztéséért, megkötéséért, magáért a szerződési ígéret tartalmáért. ${ }^{26}$ Mindaddig, míg a joggyakorlat és a tudományos közélet is alapvetően a közjogi kényszer, azaz a normatív szabályozás tar-

${ }^{23}$ KISS (2020): i. m., 275-277.

${ }^{24}$ Havighurst, Harold: The Nature of Private Contract. Evanston, Illinois, Northwestern University School of Law, 1961., 128-129.

${ }^{25}$ Kiss György által idézve ilyen közvetítő normák lehetnek: role integrity, mutuality, implementation of planning, effectuation of consent, flexibility, contractual solidarity, the linking norms, creation and restraint of power, harmonization with social matrix. MACNEIL, Ian Roderick: The New Social Contract; An Inquiry into Modern Contractual Relations. Yale University Press, New Haven and London, 1979, 40-59.

${ }^{26}$ Kiss (2020): i. m., 277-279. 
talmának helyes meghatározására fekteti a hangsúlyt, és ezzel a szerződésért való felelősség súlyát - legalábbis részben - leveszi a felek válláról, addig a munkajog ilyen irányú fejlődése elmarad. Azonban mérhetetlenül kockázatos annak az elvárása, hogy ez önként meg fog történni. Vannak ebben, az önkéntesség irányában előremutató koncepciók, lásd például a társadalmilag felelős vállalatirányítási elméleteket (CSR - Corporate Social Responsibility) vagy a szervezetfejlesztés irányából kinőtt emberi erőforrás gazdálkodás (HRM - Human Resource Management) szervezeti feladatait meghatározó irányítási modellt. Azonban ezek egyikének sem kötelmi jogi, szerződéses elvek a kiindulási alapjai, hanem sokkal inkább, a munkáltató önkéntes felelősségvállalásán vagy gazdasági érdekein alapuló egyoldalú szabályozási koncepciókban való gondolkodás. Ezen az úton érhetőek el munkajogi eredmények, különösen az egyéni érdekek szintjén, azonban a munkajog tartóssága - vagy a szerző által is remélt munkavállalói státuszállapota - nem valósítható meg.

A HRM megoldások és munkajogi szabályozás közötti ellentmondások értékelésére számos eszköz áll a rendelkezésünkre - gondoljunk akárcsak Deakin teóriájá$\mathrm{ra}^{27}$ - amely a piac és a munkajog egymásra gyakorolt hatását elemzi. A munkajogi keretek meghatározásakor nem hagyhatóak figyelmen kívül azok a munkaeröpiaci folyamatok, melyek a foglalkoztatás hátterét biztosítják, hiszen ebben a közegben van szükség a munkajogi szabályok felállítására. ${ }^{28} \mathrm{~A}$ probléma nehézségét az adja, hogy nem szorítkozhatunk a közjogi keretek kijelölésekor a munkaerőpiac elvárásainak biztosítására, hiszen a normatív szabályozás lényege éppen a tartós foglalkoztatás elérése, mely egyúttal a munkavállalói státuszbiztonság elérése érdekében tett lépésként is értékelendő, még abban az esetben is, amikor a munkaszerződés szerző által vizsgált kötelmi jellegének megteremtését tűzzük ki célul. Kiss György által definiálva a helyzetet: „A foglalkoztatásra tett munkáltatói ígéret önmagában labilis, így az ilyen tartalmú ígéretet a jogrend valamilyen módon átalakítja." 29

A relation contract munkajogi keretek közötti vizsgálata is az angolszász irodalomból eredeztethető, Bird a manager contract fogalmát elemezve jutott el arra a következtetésre, hogy a munkajogviszonyt szabályozó joganyag és a ténylegesen érvényesülő normák - érthetjük ezalatt akár a munkáltató belső szabályozási vagy íratlan gyakorlaton alapuló irányítási rendszerét - között diszkrepancia van és a szerződés mellett a beleértett feltételek alkalmazására kerül sor. Ezen logikai okfejtés végeként a munkaszerződést is egy relational contractnak minősíti a szerző. ${ }^{30}$

\footnotetext{
${ }^{27}$ Deakin, Simon: The Contribution of Labour Law to Economic and Human Development, In: Davidov, Guy \& Langille, Brian (eds.): The Idea of Labour Law. Oxford University Press, 2011, 156-179.

${ }^{28}$ Utalhatunk még a Kiss György által is hivatkozott munkákra, melyekben megfogalmazásra kerül, hogy a szerződés tartalmát egyre inkább olyan tényezők befolyásolják, amelyek a gazdasági magatartás egyéb dimenzióit is. FRIEdmAN, Lawrence: Contract Law in America. A Social and Economic Case Study. New Orleans, Luisiana, 1965; vagy GILMORE, Grant: The Death of Contract. Columbus, Ohio State University Press, 1974.

${ }^{29}$ Kiss (2020): i. m., 140.

${ }^{30}$ BIRD, C. Robert: Employment as a relational contract. U. Pa. Journal of Labor and Employment Law, 2005, $149-151$.
} 
A munkaszerződés mellett jelentősége van a beleértett feltételeknek - amiket a relation contract implied terms-ként különös jelentőséggel ruház fel, azonban más elméletek is ugyanezen tényekből kiindulva elemzik a felek közötti szerződésbe beleértett, megszövegezésre nem kerülő rejtett feltételeket. A „pszichológiai szerződés" elméletét ${ }^{31}$ alapul véve van egy megkötött szerződés a munkajog és a kötelmi jog szabályai szerint, és van egy „pszichológiai szerződés”, mely az egyén kölcsönös elköteleződésbe vetett személyes hitén alapul. ${ }^{32}$ Látható, hogy más úton, de ez az elmélet is a munkajog sajátosságait kívánja leírni, szintúgy a tartósság - alakító jog - státuszjogviszony koordinátarendszerében. A munkajog korábban felvázolt útkeresésének problémája megállapíthatóan a munkaszerződés célja, a szabályozás módszere körében, azaz a munkajogot meghatározó környezet és a munkajogviszony tartalmi egyezőségében érhető tetten. A dilemma feloldására több kísérlet történt.

A Kiss György által javasolt „három feltétel, illetve követelmény szükséges ahhoz, hogy a munkaszerződés és a munkaviszony a jelenlegi állapotánál jobban érvényesítse a kontraktualitás elvét." Egyrészt a munkaszerződés központi szerepének megőrzése; másrészt a munkáltató szerződést alakító szerepére, a felek közötti autonómia egyensúly kialakítására tekintettel a kollektív munkajog intézményeinek meghatározó befolyása (az általános szerződési feltételek szerinti szerződéses kontroll); és végezetül a munkajogviszony tartósságának, a munkavállaló státuszbiztonságának garantálása. ${ }^{33}$

Az általunk felvázolt és a tudományos közvélemény mellett a joggyakorlatban is elterjedt megoldások nem ebbe az irányba hatnak, a soft law megoldások alkalmazása révén igyekeznek elkerülni a tételes jogi szabályozást, azonban a kollektív munkajogi megoldások alkalmazása helyett is inkább az egyoldalú szabályzatok szintjén alkotnak rendelkezéseket, azaz sem a sátuszbiztonság, sem az általános szerződési feltételek biztosítéka nem segíti elő a jogviszony tartóssá válását. Megítélésünk szerint ezen fejlődési irányok mindaddig dominánsak lesznek, amíg a jogalkalmazók, azaz a munkaerőpiac szintjén nem merül fel az igény a kötelem tartósságára. Kiss György monográfiája reményeink szerint felnyitja ekörben a jogalkotó és a tudományos közélet szemét is.

\footnotetext{
${ }^{31}$ A szervezetszociológa keretei közé a kérdést Rousseau munkássága emelte be. Lásd RoussEAU, Denise: Psychological contracts in organizations: Understanding written and unwritten agreements. Sage Publications, Thousand Oaks, London, New Delhi, 1995.

32 Robinson, Sandra L.: Trust and breach of the psychological contract. Administrative Science Quarterly, 1996, 22.

${ }^{33}$ Kiss (2020): i. m., 278-279.
} 